\title{
UVODNIK
}

\section{CIVILNO-VOJAŠKI ODNOSI}

Tako smo poimenovali letošnjo prvo številko in civilno-vojaški odnosi bodo vodilna tema tudi pri naslednjih treh številkah, ki jih načrtujemo za letos. V drugi številki bi želeli izvedeti, kaj je novega v razvoju obrambnega sistema, v tretji se želimo posvetiti novim nevojaškim grožnjam, ki se pojavljajo v obliki kibernetskih groženj in različnih bolezni, kot je na primer ebola, in problematiki povečanih migracij iz afriške smeri proti evropskim mejam. V četrti številki pa se bomo spomnili stote obletnice nastanka soške fronte.

Pricivilno-vojaških odnosih gre za odnos med civilno družbo in vojaškimi organizacijami. Ko se njihove vsebine lotimo podrobneje, ugotovimo, da gre za oblike nadzora civilne družbe nad vojaško organizacijo. Prva avtorja, ki sta se posvetila tem odnosom, sta Sun $\mathrm{Cu}$, okrog 500 let pred našim štetjem, in Carl von Clausewitz, na prehodu iz 17. v 18. stoletje. Izhajala sta iz dejstva, da je vojska v službi države. V akademske vode politologije in sociologije sta civilno-vojaške odnose uvedla Samual P. Huntington in Morris Janowitz. Veliko literature o tem je nastalo v obdobju po drugi svetovni vojni, vse do padca berlinskega zidu. Preoblikovanje vojsk kot posledica konca blokovske delitve zahodnega dela sveta je veliko prispevalo k nastanku različne literature, s poudarkom na transformacijski paradigmi, ki se razvija predvsem znotraj Nata.

Po letu 2010 v Sloveniji lahko ugotovimo, da področje vojaške strokovne in znanstvene literature nazaduje. Čeprav varnostnih, obrambnih in vojaških izzivov ne manjka, $\mathrm{v}$ akademskih in strokovnih krogih ni prave motivacije za organizacijo dogodkov, na katerih bi izmenjali zamisli in kritične misli ter odzive nanje. Ker takih dodatnih spodbud ni, se zdi nekako logično, da na te teme tudi ni člankov, monografij in učbenikov.

Kaj lahko naredimo, da spodbudimo razprave o civilno-vojaških odnosih, varnosti, obrambi in vojski, da bodo nastali tudi kakovostni zapisi za druge - študente, mlade, veterane, strokovno in znanstveno javnost ter civilno družbo? 
Ena izmed možnosti, ki jih ima Slovenska vojska oziroma Generalštab Slovenske vojske kot izdajatelj te publikacije, je spodbujanje zaposlenih in tistih, ki z vojsko in ministrstvom sodelujejo, k pisanju. Rezultat teh spodbud so članki v tej številki.

Gregor Garb v članku z naslovom Uveljavljanje zasebnih vojaških družb skozi prizmo globalizirane varnosti izhaja iz spremenjenega političnega in varnostnega okolja, ki je povzročilo, da so se v strokovnih varnostnih krogih začeli poleg tradicionalnih omenjati tudi nedržavni akterji z nadnacionalnimi povezavami in vplivi. Temo je leta 2004 že načel profesor Žabkar v poglavju Ali je v prvih letih tretjega tisočletja prišlo do privatizacije vojaškega poklica, objavljenem v drugem delu monografije z naslovom Marsova dediščina. Dobrih deset let pozneje Garb predstavlja svoje ugotovitve.

József Padányi in László Földi predstavljata različne izkušnje madžarske vojske v mednarodnih operacijah in na misijah ter njeno pomoč prebivalstvu ob naravnih in drugih nesrečah. Madžarska vojska je leta 2010 sodelovala pri odpravi velike nesreče z izlivom rdečega blata. Več o tem v članku Naloge in izkušnje madžarske vojske pri kriznem upravljanju.

Konec lanskega leta je zavezništvo končalo operacijo Isafa v Afganistanu. Tam so bili deset let del zavezniških sil tudi pripadniki Slovenske vojske. O poslanstvu, nalogah in izkušnjah Enote za specialno delovanje je Kristian Beršnak napisal članek z naslovom Razvoj specialnih sil SV in izkušnje iz Afganistana.

Spoprijemanje z današnjimi izzivi določa uporabo širokega spektra civilnih in vojaških zmogljivosti, izboljšano sodelovanje ter usklajevanje vseh vključenih subjektov in tudi pripravo enotnega subjekta nacionalne varnosti, piše Andrej Androjna v članku z naslovom Obalna straža - dejavnik povečanja varnosti v pomorskem prometu, v katerem proučuje drugačne možnosti zagotavljanja te oblike varnosti.

Andrej Skvarča v članku Uporabnost programskega orodja Topobase pri upravljanju nepremičnin v obrambnem resorju opisuje programsko orodje, ki ga uporabljajo na Letališču Cerklje ob Krki. V času, ko je zaščita kritične infrastrukture vedno bolj pomembna, se zdi smiselno to programsko orodje uporabljati tudi širše v obrambnem sistemu.

Toliko smo se pri tej številki angažirali v Slovenski vojski. Ali se morda še kje kdo ukvarja z obrambno-vojaškimi vsebinami? Imamo nekaj slovenskih fakultet s katedrami, ki se ukvarjajo z različnimi varnostnimi vsebinami. Imamo nekaj ustanov, za katere lahko rečemo, da so »think tank«, kot angleško govoreče okolje imenuje ustanove, ki veljajo za možgansko središče novih zamisli.

Smo morda v Sloveniji brez novih zamisli na področju varnosti? Morda pa jih imamo, a so ostale nekje v etru, ker jih nihče ne zapiše v strokovnem ali znanstvenem članku. 